\title{
Electrooxidation of simulated wastewater containing pharmaceutical amoxicillin on thermally prepared $\mathrm{IrO}_{2} / \mathrm{Ti}$ electrode
}

\author{
Foffié Thiery Auguste Appia and Lassiné Ouattara* \\ Laboratoire de constitution et de réaction de la matière, UFR SSMT, Université Félix Houphouët-Boigny de \\ Cocody, Abidjan, 22 BP 582 Abidjan 22, Côte d'Ivoire
}

\begin{abstract}
The electrooxidation of amoxicillin (AMX) on the iridium oxide electrode thermally prepared $\left(400^{\circ} \mathrm{C}\right)$ has been investigated by cyclic voltammetry and preparative electrolysis. Physical characterization by Scanning Electron Microscopy (SEM) showed that the $\mathrm{IrO}_{2}$ electrode has a rough surface with pores' presence. In cyclic voltammetry, the oxidation of AMX occurs directly at the anode's surface or via the higher degree oxide of iridium oxide $\left(\mathrm{IrO}_{3}\right)$. It is noted that the oxidation process of AMX can be controlled by diffusion combined with the phenomenon of adsorption. In preparative electrolysis, the effect of several parameters has been investigated. These are the current density, the support medium, the initial $\mathrm{pH}$. The findings obtained show a weak degradation of amoxicillin. The Chemical Oxygen Demand (COD) reduction rate is less than $11 \%$ under our experimental conditions, indicating that the $\mathrm{IrO}_{2}$ electrode leads to the parent compound's conversion. Also, the degradation of the organic compound is favored in a very acidic medium.

Furthermore, the effect of inorganic ions such as $\mathrm{SO}_{4}{ }^{2-}, \mathrm{PO}_{4}{ }^{3-}, \mathrm{NO}_{3}{ }^{-}, \mathrm{Cl}^{-}$was evaluated. Investigations show that these ions' effects are diverse, with COD reduction rates ranging from $2.47 \% ; 2.68 \% ; 7.7 \% ; 16.41 \%$, and $71.65 \%$, respectively, in the absence and the presence of $\mathrm{SO}_{4}{ }^{2-}, \mathrm{PO}_{4}{ }^{3-}, \mathrm{NO}_{3}{ }^{-}, \mathrm{Cl}^{-}$ions. $\mathrm{SO}_{4}{ }^{2-}$ have virtually no effect on enhancing the degradation of amoxicillin. $\mathrm{PO}_{4}{ }^{3-}$ ions provide a slight improvement in amoxicillin degradation. As for nitrate ions, their influence is 2.31 times than that of phosphate ions. Chloride ions improve the performance of the electrooxidation of amoxicillin on $\mathrm{IrO}_{2}$ very significantly. The presence of chloride ions makes it possible to go from 2928.35 (absence of inorganic ions) to $33.19 \mathrm{kWh}$ per Kg of COD. This represents an energy gain of over $98 \%$.
\end{abstract}

Keywords: Amoxicillin; wastewater treatment; antibiotic; DSA; active chlorine.

\section{Introduction}

The treatment of hospital wastewater before its release into the environment is a real problem in Côte d'Ivoire. Indeed, the wastewater from the teaching hospital of Treichville in Abidjan is directly discharged into the lagoon without any treatment. The said center has a wastewater treatment plant that has not been operating since 1975. According to a survey conducted by our laboratory in this great hospital, the actual wastewater from its various services contains inorganic ions, including chloride, sulfate, nitrate, and phosphate ions ${ }^{1}$. It has also shown that amoxicillin is one of the most prescribed antibiotics for hospital patients after ceftriaxone and augmentin. However, it has been proven that the body partially metabolizes most antibiotics administered to patients, and 25-75\% of the antibiotic fractions are released into the environment via urine and feces ${ }^{2,3}$ in unchanged form after administration. The continued rejection of these pharmaceutical compounds can pose a real threat to the aquatic ecosystem and human health in the long term $^{4,5}$.

Some authors have shown residues of pharmaceutical compounds, particularly antibiotics, in the soil, urban wastewater, groundwater, and surface water ${ }^{6-8}$ at concentrations ranging from $\mathrm{ng} / \mathrm{L}$ to $\mu \mathrm{g} / \mathrm{L}{ }^{9}$. The presence and accumulation of many antibiotics in the environment can have adverse effects on aquatic and terrestrial organisms, such as changes in behavior, reproduction, and growth, and this, at low concentrations. For example, amoxicillin released into the environment can cause, among other things, drug allergy and toxicological problems ${ }^{10}$, antibiotics resistant bacteria (ARB), and gene resistance to antibiotics in the aquatic environment ${ }^{11,12}$.

To prevent environmental pollution from wastewater containing pharmaceuticals, several methods are 
used 13. However, numerous studies have demonstrated that the biological method, effective for

treating domestic wastewater ${ }^{14}$ is ineffective for hospital wastewater, especially those containing a large number of antibiotics due to the nonbiodegradable nature of these pharmaceutical compounds ${ }^{15}$. Consequently, the search for a technique capable of degrading all kinds of organic pollutants is essential.

In this context, electrochemical processes constitute a promising technique for treating wastewater containing biorecalcitrant organic pollutants. Various studies on the treatment of wastewater containing pharmaceutical compounds by the electrochemical method have been carried out ${ }^{15,17,18}$. Degradation of a pollutant by electrooxidation can convert the parent organic compound to other intermediates or their mineralization of the parent compound ${ }^{19-21}$. There are two types of electrochemical oxidation mechanism; these are direct electrochemical oxidation and indirect electrochemical oxidation. In direct electrochemical oxidation, the initial compound can be directly converted or eliminated by an electrochemical reaction. Concerning indirect electrochemical oxidation, the initial compound is oxidized through the intermediary of strong redox oxidative species such as hydroxyl radicals or other oxidizing species formed from water or other species discharging the surface of the anode at a high current. These active species can lead to the conversion or the mineralization of the initial organic compound. In electrochemistry, the type of material used in the anode plays a crucial role in its efficiency. Therefore, the same organic pollutants and their reaction intermediates produced will have different reaction rates with other electrodes ${ }^{22}$. The BDD electrode is commonly used for the degradation of pharmaceutical compounds ${ }^{23,24}$. This electrode has an inert surface with low adsorption properties, high corrosion stability (even in strongly acidic media), and a much higher overpotential for oxygen release than other conventional anodes such as Pt, DSA (Dimensionally
Stable Anodes) ${ }^{25}$. However, its use is minimal due to its high cost.

On the other hand, the use of DSA for the degradation of organic pollutants makes it possible to reduce the cost of investment and operation compared to borondoped diamond (BDD). These electrodes exhibit high electrocatalytic activity, high stability against anodic corrosion, and very high mechanical stability. Among the DSA commonly used in the degradation of organic pollutants, $\mathrm{IrO}_{2}$ exhibits good electrocatalytic properties to form active chlorine species from chloride ions ${ }^{26}$. Several authors have investigated the degradation of organic contaminants on the $\mathrm{IrO}_{2}$ electrode alone or combined with other precursors $\left(\mathrm{RuO}_{2}, \mathrm{Pt} \text {, etc. }\right)^{27-29}$. However, there is no study on the effect of various inorganic ions on the degradation of amoxicillin on the $\mathrm{IrO}_{2} / \mathrm{Ti}$ electrode to our knowledge. In this work, the iridium oxide $\left(\mathrm{IrO}_{2}\right)$ electrode thermally prepared at $400^{\circ} \mathrm{C}$ will be used to treat simulated wastewater polluting amoxicillin. Several parameters, such as the effect of the current applied density, the support medium, the $\mathrm{pH}$, and the presence of the inorganic ions $\left(\mathrm{SO}_{4}^{2-}, \mathrm{PO}^{3-}, \mathrm{NO}_{3}^{-}, \mathrm{Cl}^{-}\right)$, are found most often in hospital wastewater, have been investigated. This work was carried out to apply its results to the treatment of real hospital wastewater from the Treichville Hospital and University Center (CHU) in Abidjan.

\section{Experimental}

\subsection{Chemicals}

Amoxicillin tablets (Table 1) made by Bailly-Creat laboratory were purchased from a pharmacy in Abidjan and used in its formula commercial. Tablets have been crushed before use. All chemicals used in the study were reagent grade or higher and used as received without further purification. Potassium perchlorate $\left(\mathrm{KClO}_{4}\right)$, perchloric acid $\left(\mathrm{HClO}_{4}\right)$, potassium nitrate $\left(\mathrm{KNO}_{3}\right)$, sodium chloride $(\mathrm{NaCl})$, potassium sulfate $\left(\mathrm{K}_{2} \mathrm{SO}_{4}\right)$, potassium dihydrogen phosphate $\left(\mathrm{K}_{2} \mathrm{HPO}_{4}\right)$ were obtained from Fluka. Solutions were prepared with distilled water. $\mathrm{HClO}_{4}$ and $\mathrm{NaOH}$ (Fluka) allowed adjusting the $\mathrm{pH}$ value.

Table 1. Chemical and physical characteristics of amoxicillin.

\begin{tabular}{|c|c|}
\hline Therapeutic class & Bactiricidal $\beta$-lactam antibiotic \\
\hline Brute formula & \\
\hline Developed formula & $3430 \mathrm{mg} / \mathrm{L} \mathrm{water} \mathrm{at} 25^{\circ} \mathrm{C}$ \\
\hline Molar mass & 2.8 \\
\hline Melting point & $365.4 \mathrm{~g} / \mathrm{mol}^{\circ}$ \\
\hline pKa & \\
\hline Solubility &
\end{tabular}




\subsection{Preparation of $\mathrm{IrO}_{2} / \mathrm{Ti}$ electrode}

The $\mathrm{IrO}_{2} / \mathrm{Ti}$ electrode was prepared, thermally at $400^{\circ} \mathrm{C}$, in our laboratory with an appropriate metallic precursor. The coating precursor was prepared from $\mathrm{H}_{2} \mathrm{IrCl}_{6}, 6 \mathrm{H}_{2} \mathrm{O}$ (Fluka). The precursor was dissolved in pure isopropanol (Fluka) used as a solvent. The preparation procedure is the same as that described in our previous work ${ }^{30}$. The titanium substrate was sandblasted to ensure good adhesion of the deposit on its surface. After sandblasting, the substrate was treated using water and isopropanol to clean its surface from residual sands. The substrate was then dried in an oven at $80^{\circ} \mathrm{C}$ and weighed. After that, the precursor was applied by a painting procedure on cleaned titanium (Ti) substrate then put in an oven for $15 \mathrm{~min}$ at $80^{\circ} \mathrm{C}$ to allow the solvent's evaporation fired at $400^{\circ} \mathrm{C}$ in the furnace for $15 \mathrm{~min}$ to allow the decomposition of the precursor. These steps were repeated five times to achieve the desired weight of the coating is reached. A final decomposition of $1 \mathrm{~h}$ was done at $400^{\circ} \mathrm{C}$. The deposit loading was about $5 \mathrm{~g} \cdot \mathrm{m}^{-2}$.

\subsection{Cyclic voltammetry}

Cyclic voltammetry (CV) was performed in a conventional three-electrode cell using a computercontrolled Autolab potentiostat PGSTAT 20 (ECHOCHEMIE). $\mathrm{IrO}_{2} / \mathrm{Ti}$ electrode, prepared thermally, was used as the working electrode, saturated calomel electrode $\mathrm{Hg} / \mathrm{Hg}_{2} \mathrm{Cl}_{2} / \mathrm{KCl}$ as reference electrode, and $\mathrm{Pt}$ wire as the counter electrode. The geometric area of the working electrode that is in contact with the supporting electrolyte is $1 \mathrm{~cm}^{2}$. The electrode reference is put in a capillary luggin whose end is placed very close to the working electrode to reduce the ohmic drop. The potential of the electrode was reported relative to the saturated calomel electrode (SCE). The electrolyte was either $0.1 \mathrm{M} \mathrm{KClO}_{4}$. Solutions were magnetically stirred during the experiments.

\subsection{Electrooxidation experiments}

The Electrooxidation experiments were performed in an undivided cylindrical electrochemical cell of 250
$\mathrm{mL}$ capacity in a galvanostatic regime and magnatically stirred. The solution flow rate was 2.08 $\mathrm{mL} \mathrm{s}^{-1}$. In the reactor, the solution is recirculated using a mini peristaltic pump. All the experiments were done at the ambient temperature of $22-25^{\circ} \mathrm{C}$. The anode was $\mathrm{IrO}_{2} / \mathrm{Ti}$, and Zirconium $(\mathrm{Zr})$ plates were used as cathode. During each electrolytic run, a sample of $2 \mathrm{~mL}$ was drawn from the reactor at defined time intervals and analyzed in COD. Representative runs were performed in triplicate to check for reproducibility, which was found to be quite good.

\subsection{Analytical}

The COD of the samples was determined during our experiments using $\mathrm{HACH}$ brand COD tubes. To determine it, $2 \mathrm{~mL}$ of sample is taken and introduced into a COD tube and heated in a digester $(\mathrm{HACH})$ at $150^{\circ} \mathrm{C}$ for 120 minutes. After cooling, the COD value is read directly using the DR/6000 spectrophotometer $(\mathrm{HACH})$ at a wavelength of $420 \mathrm{~nm}$ for the range 10-150 ppm.

COD abatement rate is determined using this formula:

$\Delta(\mathrm{COD})=\frac{\mathrm{COD}_{0}-\mathrm{COD}_{\mathrm{t}}}{\mathrm{COD}_{0}} * 100$

Where $\mathrm{COD}_{0}$ and $\mathrm{COD}_{\mathrm{t}}$ are respectively the initial $\mathrm{COD}$ and the final $\mathrm{COD}\left(\mathrm{mg} \mathrm{O}_{2} / \mathrm{L}\right)$.

Normalized COD (COD*) is calculated from relation 2

$$
C O D^{*}=\frac{\mathrm{COD}_{0}-\mathrm{COD}_{\mathrm{t}}}{\mathrm{COD}_{0}}
$$

\section{Results and discussion}

\subsection{Morphological characterization of prepared electrode}

Figure 1 shows the SEM representation of the microphoto of the thermally prepared $\mathrm{IrO}_{2}$ electrode. The pure iridium dioxide $\left(\mathrm{IrO}_{2}\right)$ electrode's surface shows overlapping layers of iridium dioxide, cracks, and pores. The thermal shock to which the deposits are subjected during their removal from the oven is the cause of the various cracks observed on the surface of the electrodes prepared thermally at $400^{\circ} \mathrm{C}$.

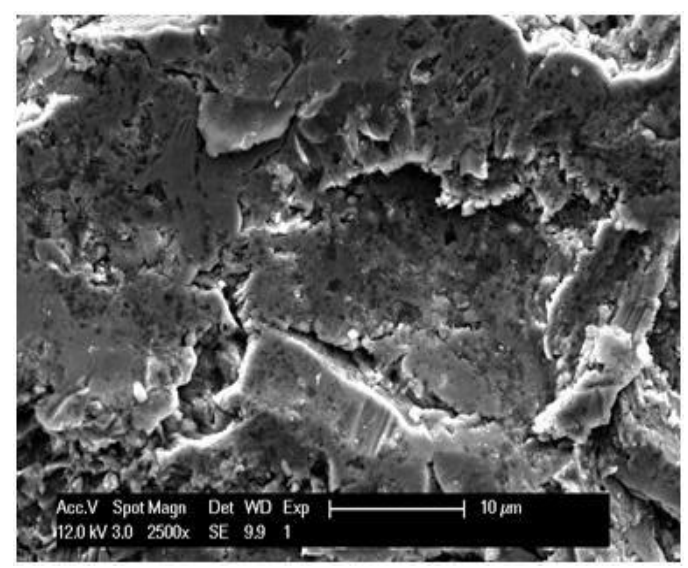

Figure 1. SEM image of $\mathrm{IrO}_{2}$ deposit on Titanium 


\subsection{Cyclic voltammetry}

Cyclic voltammetry is a technique commonly used in electrochemistry for the electrochemical characterization of electrodes. This technique makes it possible to understand the behavior of the electrode. Figure 2 (i) shows the cyclic voltammograms of the $\mathrm{IrO}_{2}$ electrode in the absence and presence of amoxicillin $(1 \mathrm{~g} / \mathrm{L})$ in the potential range from $-0.38 \mathrm{~V}$ to $1.24 \mathrm{~V}$. The supporting electrolyte used is $0.1 \mathrm{M}$ $\mathrm{KClO}_{4}$.

In the absence of amoxicillin (curve (a)), we note the presence of an anode wave between $0.7 \mathrm{~V}$ and $1.1 \mathrm{~V}$, which could be attributed to the redox transitions $\operatorname{Ir}(\mathrm{III}) / \mathrm{Ir}(\mathrm{IV})$ and $\operatorname{Ir}(\mathrm{IV}) / \operatorname{Ir}(\mathrm{VI})^{31,32}$. The evolution of oxygen characterized by a rapid increase in oxygen starts from $1.19 \mathrm{~V}$. In the presence of amoxicillin (curve (b)), an increase in the voltammetric charge in the anode part is observed from $0.48 \mathrm{~V}$, which is before the release of oxygen. That would reflect the start of the oxidation of amoxicillin in the supporting electrolyte's stability domain on $\mathrm{IrO}_{2}$. This indicates that the oxidation of amoxicillin on the electrode of the $\mathrm{IrO}_{2}$ electrode occurs by a direct electronic exchange on the electrode's surface.
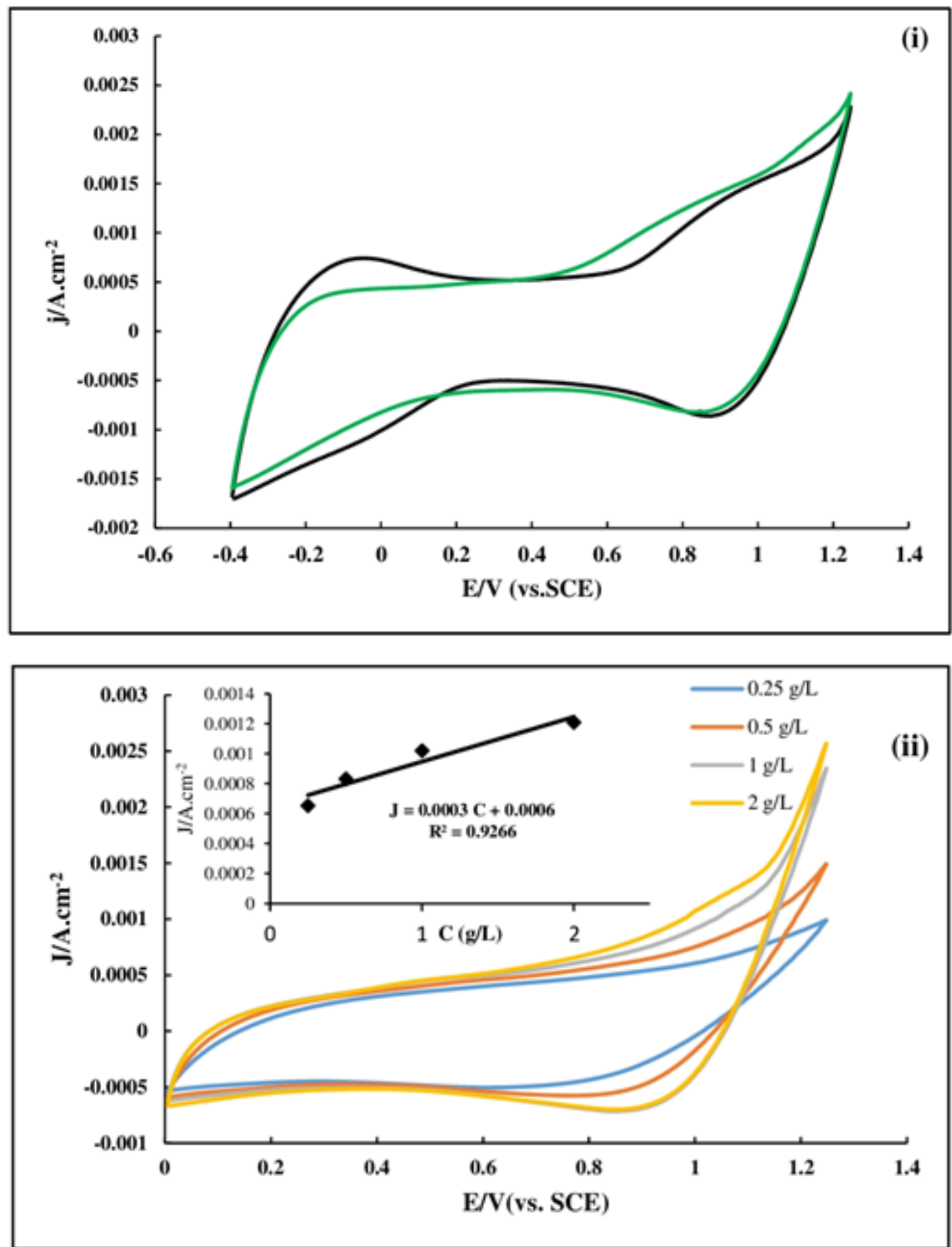

Figure 2. (i): Cyclic voltammograms in the absence (a) and in the presence (b) of amoxicillin on an iridium oxide $\left(\mathrm{IrO}_{2}\right)$ electrode in $0.1 \mathrm{M} \mathrm{KClO}_{4} \mathrm{ER}$ : ECS; CE: platinum wound, $\mathrm{T}=25^{\circ} \mathrm{C}, \mathrm{v}=8 \mathrm{mV} / \mathrm{s}$.

(ii): cyclic voltammogram recorded on $\mathrm{IrO}_{2} / \mathrm{Ti}$ electrode in $0.1 \mathrm{M} \mathrm{KClO}_{4}$ for various concentration of $\mathrm{AMX}$. CE: platinum wound; $\mathrm{T}=25^{\circ} \mathrm{C}, \mathrm{v}=8 \mathrm{mV} / \mathrm{s}$.

Insert: Evolution of the current density as a function of the concentration of amoxicillin for $\mathrm{E}=1.05 \mathrm{~V}$ 
According to the literature ${ }^{33,34}$, the oxidation of the organic compound can result from the higher degree oxide $\mathrm{IrO}_{3}$ generated on the surface of the $\mathrm{IrO}_{2}$ from the decomposition of water (Eqs.(3)-(5))

$$
\begin{aligned}
& \mathrm{IrO}_{2}+\mathrm{H}_{2} \mathrm{O} \rightarrow \mathrm{IrO}_{2}\left({ }^{\circ} \mathrm{OH}\right)+\mathrm{H}^{+}+\mathrm{e}^{-} \\
& \mathrm{IrO}_{2}\left({ }^{\circ} \mathrm{OH}\right) \rightarrow \mathrm{IrO}_{3}+\mathrm{H}^{+}+\mathrm{e}^{-} \\
& \mathrm{IrO}_{3}+\mathrm{AMX} \rightarrow \mathrm{IrO}_{2}+\text { product }
\end{aligned}
$$

The effect of amoxicillin concentration has been investigated in the range $0.25 \mathrm{~g} / \mathrm{L}$ to $2 \mathrm{~g} / \mathrm{L}$ in the positive potential domain. The results are presented in Figure 2 (ii).
In this figure, the current density increases with the concentration. For a potential fixed at $1.05 \mathrm{~V}$, the current densities have been recorded and plotted against the concentration (insert of Figure 2 (ii)). A linear relationship of equation $\mathrm{J}=0.0003 \mathrm{C}+0.0006$ with a correlation coefficient $\mathrm{R}^{2}=0.9266$ was obtained. This attests that these current densities are directly linked to amoxicillin oxidation for the concentration range explored.

Figure 3 shows the consecutive cyclic voltammograms of $1 \mathrm{~g} / \mathrm{L}$ of amoxicillin in $0.1 \mathrm{M}$ $\mathrm{KClO}_{4}$ at the potential scan of $8 \mathrm{mV} / \mathrm{s}$ between the potentials $-0.4 \mathrm{~V}$ and $1.2 \mathrm{~V}$.

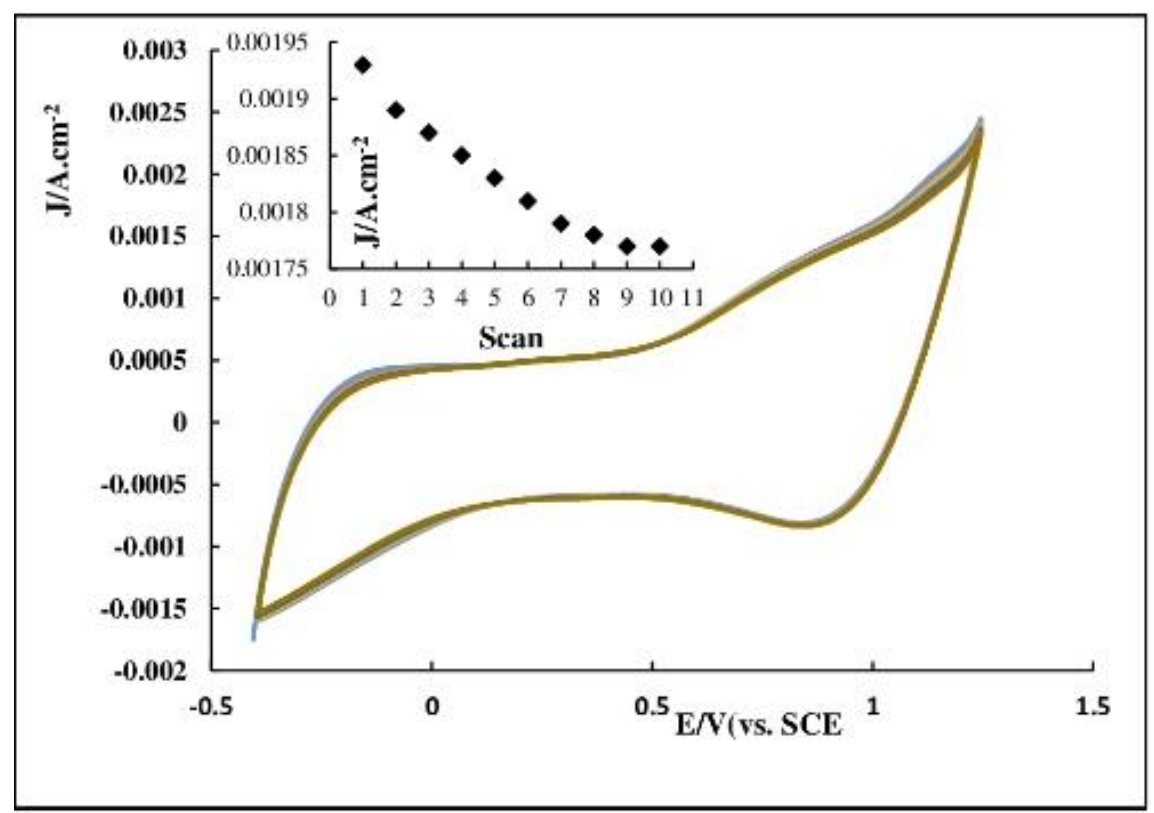

Figure 3. Cyclic voltammogram of amoxicillin $(1 \mathrm{~g} / \mathrm{L})$ on iridium oxide electrode in $0.1 \mathrm{M} \mathrm{KClO}_{4}$ at several scans; ER: SCE, CE: platinum, $\mathrm{T}=25^{\circ} \mathrm{C}, \mathrm{v}=8 \mathrm{mV} / \mathrm{s}$.

Inset: Evolution of the current density according to the scan for $1 \mathrm{~g} / \mathrm{L}$ of amoxicillin at $\mathrm{E}=1.05 \mathrm{~V}$

For a potential fixed at $1.12 \mathrm{~V}$, the current densities for different scans have been recorded (Insert of Figure 3.

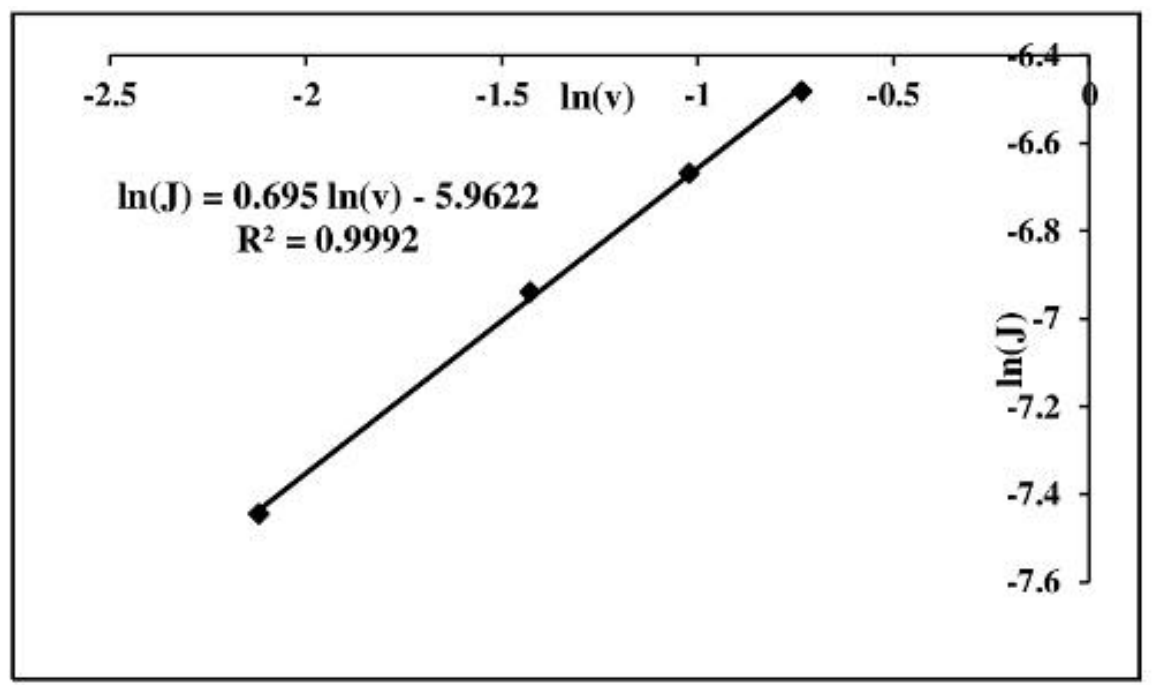

Figure 4. Evolution of the Ln of the oxidation wave of current density at $1 \mathrm{~V}$ against the Ln of the scan rate of potential 
At this potential, the anode current density decrease gradually until the scan 9 and seems to be constant from this scan. The decrease of the current density would reflect the reduction of the

electroactivity of $\mathrm{IrO}_{2}$ electrode. Other authors have made such observations on the $\mathrm{IrO}_{2}$ electrode ${ }^{35,36}$. The decrease of the electroactivity of $\mathrm{IrO}_{2}$ electrode would be mainly linked to the production and adsorption of polymer film on the surface of the electrode ${ }^{35,36}$. The effect of the potential scan rate on the oxidation of amoxicillin has been investigated. Scan rates varying from $2 \mathrm{mV} / \mathrm{s}$ to $8 \mathrm{mV} / \mathrm{s}$. The current densities were recorded for a potential fixed at $1 \mathrm{~V}$. The construction of $\ln (\mathrm{J})$ against $\ln (\mathrm{v})$ gives a straight line of equation (Figure 4) $\ln (\mathrm{J})=0.695 \ln (\mathrm{v})$ -5.9622 with a coefficient of determination $\mathrm{R}^{2}=0.9992$. The slope of the straight line is about 0.695 , it is between 0.5 and 1 . This indicates that the oxidation process of amoxicillin on the $\mathrm{IrO}_{2}$ electrode is controlled by diffusion combined with a phenomenon of adsorption $^{37}$.

\subsection{Electrolysis bulk}

\subsubsection{Effect of the current density}

Current density, the current per unit area of the electrode, is an essential parameter in electrooxidation. A high current density applied leads to a higher generation of reactive oxygen species (ROS) that can increase the efficiency of organic compound degradation.

Figure 5 shows the impact of the current density applied on the degradation of amoxicillin $(1 \mathrm{~g} / \mathrm{L})$ in $0.1 \mathrm{M} \mathrm{KClO}_{4}$ medium at $25^{\circ} \mathrm{C}$ during $10 \mathrm{~h}$ of electrolysis. The current densities applied are 20 and $100 \mathrm{~mA} / \mathrm{cm}^{2}$. For this purpose, the pseudo-first-order rate constants were determined using the formula:

$\operatorname{Ln}(\operatorname{COD} *)=-\mathrm{k} \times \mathrm{t}$

With $\mathrm{k}$ the rate constant in $\mathrm{h}^{-1}$ and $\mathrm{t}$ the electrolysis time in $h$.

It appears in this figure that the kinetic rate of degradation increases with the applied current density. Indeed, the kinetic constant, after $10 \mathrm{~h}$ of electrolysis, goes from $0.0024 \mathrm{~h}^{-1}$ for $20 \mathrm{~mA} / \mathrm{cm}^{2}$ to $0.0103 \mathrm{~h}^{-1}$ at $100 \mathrm{~mA} / \mathrm{cm}^{2}$, respectively. As the current density increases, the rate of degradation of amoxicillin increases.

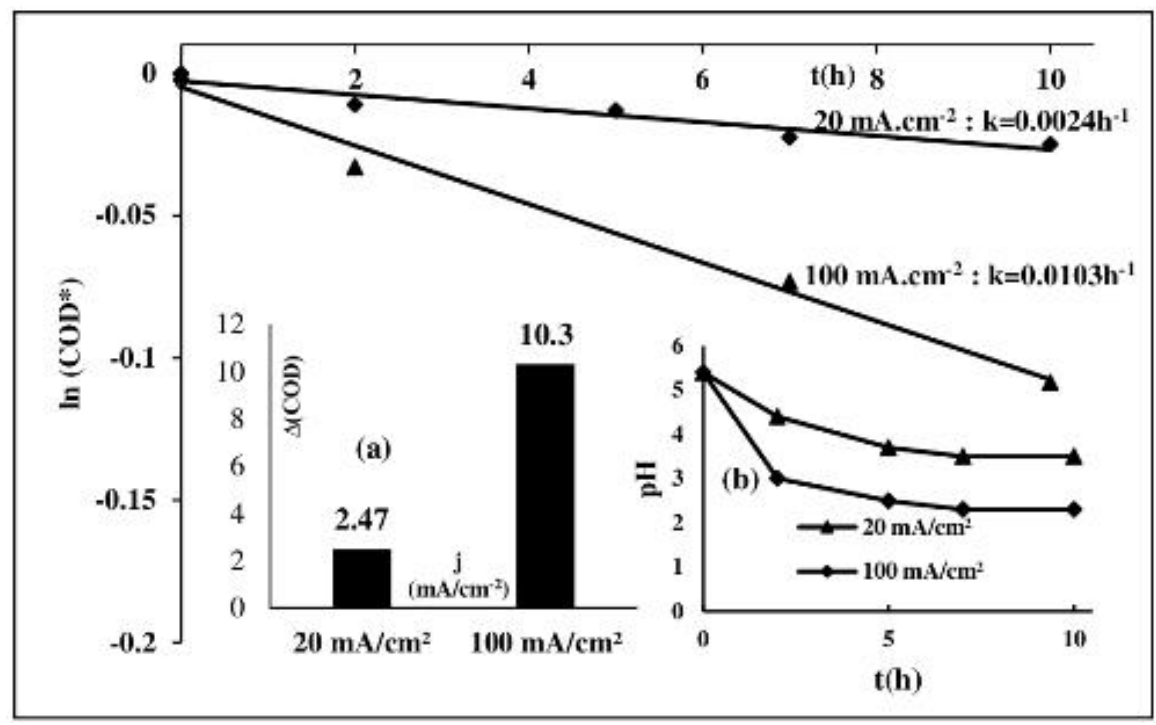

Figure 5. Plot of $\ln \left(\mathrm{COD}^{*}\right)$ versus time

Insert: plot of $\triangle \mathrm{COD} \%$ versus current density (a) and Evolution of $\mathrm{pH}$ during amoxicillin electrolysis at a different current density

The chemical oxygen demand abatement rate $(\triangle \mathrm{DCO})$ (Insert (a) in Figure 5), determined after 10 hours of electrolysis, is respectively $2.47 \%$ and $10.3 \%$ for 20 $\mathrm{mA} / \mathrm{cm}^{2}$ and $100 \mathrm{~mA} / \mathrm{cm}^{2}$. The COD abatement rate increases but slightly with current density. In general, the degradation of amoxicillin on the $\mathrm{IrO}_{2}$ electrode is very low compared to BDD electrode ${ }^{38}$. This weak degradation of amoxicillin could be due to the adsorption of intermediates formed on the electrode's surface. In addition, two mechanisms of organic compound degradation on an $\mathrm{IrO}_{2}$ electrode are possible: direct and/or mediated oxidation ${ }^{39}$. In direct oxidation, the compound is degraded by the direct electronic exchange at the electrode's surface. In a mediated oxidation, the organic compound is degraded through oxidative species or by the anode's higher oxide.

During electrolysis, the hydroxyl radicals formed from the decomposition of water interact strongly with the surface of the $\mathrm{IrO}_{2}$ anode. They, therefore, cannot participate effectively in the degradation of the organic compound. Metal cations in the oxide network can reach higher oxidation states (MOx), participating as a mediator in the oxidation of organic materials, which competes with the side reaction of the evolution of oxygen via chemical decomposition of higher oxide species. Therefore, the hydroxyl 
radicals and the higher oxide formed on the surface of the $\mathrm{IrO}_{2}$ anode promote the electrochemical conversion of organic matter into other intermediate compounds ${ }^{40}$.

The $\mathrm{pH}$ was monitored during the electrolysis. The results obtained (Insert (b) of Figure 5) show that the $\mathrm{pH}$ decreases from 5.4 to 3.5 for $20 \mathrm{~mA} / \mathrm{cm}^{2}$ and from 5.4 to 2.3 for $100 \mathrm{~mA} / \mathrm{cm}^{2}$. After 10 hours of electrolysis, the solution's $\mathrm{pH}$ is acidic, this would attest that amoxicillin's degradation leads to the formation of intermediate acid compounds.3.3.2. Effect of supporting electrolyte
The type of supporting electrolyte is a crucial parameter for the electrochemical process. The supporting electrolyte has many advantages: increase of conductivity, decrease of the medium's resistance, and therefore allow an energy gain. The effect of $0.1 \mathrm{M}$

$\mathrm{KClO}_{4}$ and $0.1 \mathrm{M} \mathrm{HClO}_{4}$ on the degradation of amoxicillin $(1 \mathrm{~g} / \mathrm{L})$ was investigated under a current density of $20 \mathrm{~mA} / \mathrm{cm}^{2}$ at a temperature of $25^{\circ} \mathrm{C}$. The results obtained are presented in Figure 6.

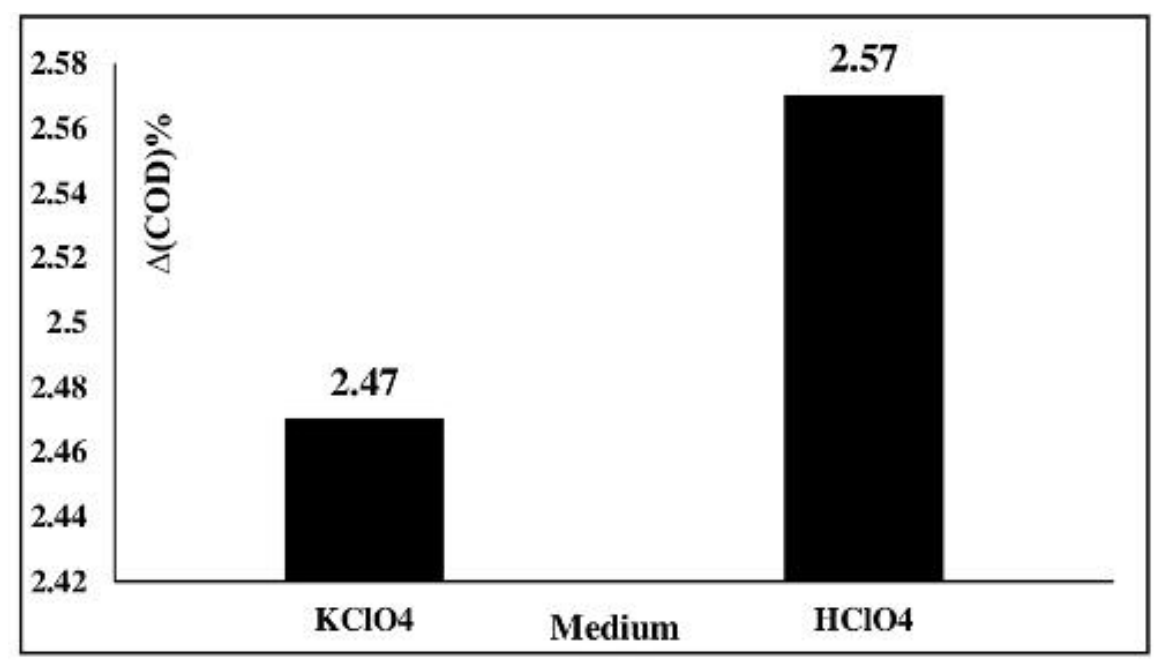

Figure 6. COD Abatement rate of amoxicillin in $0.1 \mathrm{M} \mathrm{KClO}_{4}$ and $0.1 \mathrm{M} \mathrm{HClO}_{4}$

The COD abatement rate determined after 10 hours of electrolysis is $2.47 \%$ and $2.57 \%$, respectively, in $0.1 \mathrm{M}$ $\mathrm{KClO}_{4}$ and $0.1 \mathrm{M} \mathrm{HClO}_{4}$ medium. $0.1 \mathrm{M} \mathrm{KClO}_{4}$ is less efficient for the degradation of amoxicillin $(1 \mathrm{~g} / \mathrm{L})$ than $0.1 \mathrm{M} \mathrm{HClO}_{4}$. The presence of the $\mathrm{H}+$ protons can explain these results. Additionally, the cell potential was monitored during electrolysis (data not shown). The average potential is $4.39 \mathrm{~V}$ and $8.24 \mathrm{~V}$ in $0.1 \mathrm{M}$ $\mathrm{HClO}_{4}$ and $0.1 \mathrm{M} \mathrm{KClO}_{4}$ medium, respectively. The acidic medium $\left(0.1 \mathrm{M} \mathrm{HClO}_{4}\right)$ allows an energy gain by reducing the solution's ohmic resistance.

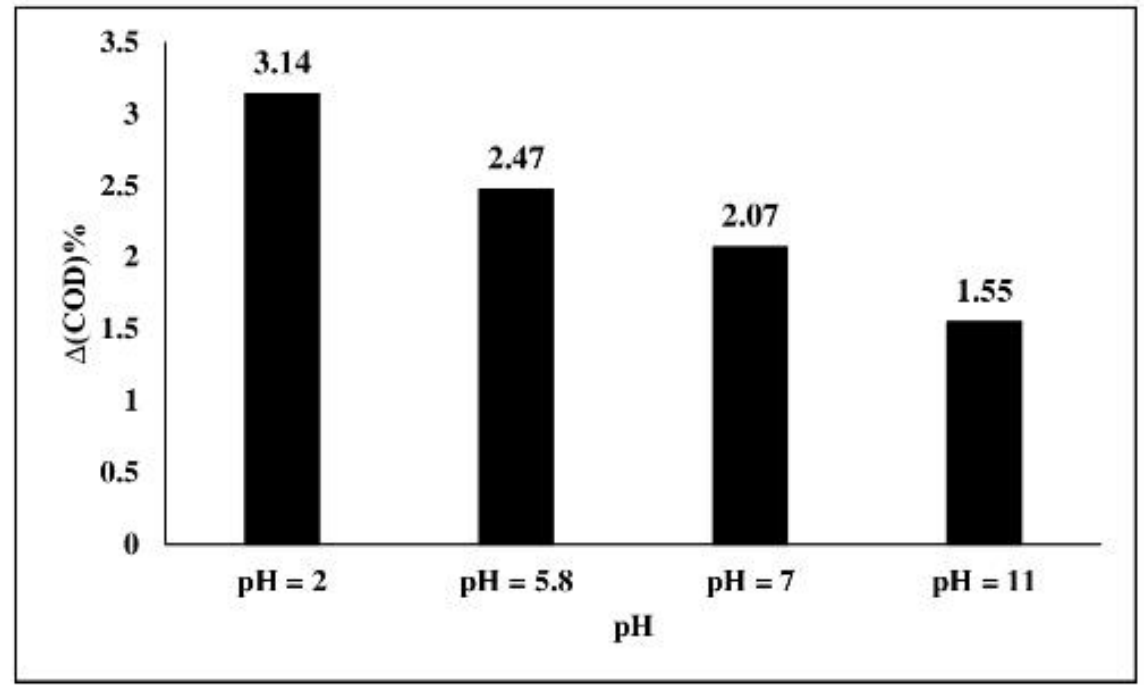

Figure 7. Amoxicillin COD reduction rate for different $\mathrm{pH}$

\subsubsection{Effect of initial $\mathrm{pH}$}

To improve the degradation rate of amoxicillin on the $\mathrm{IrO}_{2}$ electrode, investigations into the effect of $\mathrm{pH}$ were performed. The $\mathrm{pH}$ is a crucial parameter in electrooxidation because it can strongly influence the organic compound degradation rate and be responsible for generating oxidative species in solution ${ }^{41}$. To determine the effect of the initial $\mathrm{pH}$ on 
the rate of amoxicillin degradation, the measurements were carried out in a reactor stirred at a current density of $20 \mathrm{~mA} / \mathrm{cm}^{2}$. The effect of $\mathrm{pH}$ has been studied in a $\mathrm{pH}$ range of 2 to 11 for a fixed concentration of amoxicillin $(1 \mathrm{~g} / \mathrm{L})$. The results obtained are presented in Figure 7.

It showed that, after 10 hours of electrolysis, the abatement rates of the chemical oxygen demand obtained are $3.14 \%, 2.47 \%, 2.07 \%$, and $1.55 \%$ for $\mathrm{pH}$ 2, 5.8, 7, and 11, respectively. The COD abatement rate is $1.27,1.52$, and 2.03 times greater at $\mathrm{pH} 2$ than at $\mathrm{pH} 5.8,7,11$, respectively. The degradation of amoxicillin appears to be better in acidic media than in neutral and alkaline media. Some authors have shown that acidic medium promotes organic compound degradation by inhibiting the oxygen evolution reaction ${ }^{42,43}$. That could explain the enhancement of amoxicillin degradation efficiency at $\mathrm{pH}$ 2. It has been demonstrated that the oxidation of organic compounds is more favorable in an acidic medium ${ }^{42,44}$. Moreover, the best elimination of AMX obtained at $\mathrm{pH} 2$ could also be linked to amoxicillin $\mathrm{pKa}$, which is 2.8 close to $\mathrm{pH} 2$. It would be more susceptible to electrophilic attack at this $\mathrm{pH}$ than in a weakly acidic or alkaline medium ${ }^{45,46}$.

Additionally, we could add the probable formation of oxidative species such as $\mathrm{Cl}_{2}$ from supporting electrolyte $\left(\mathrm{KClO}_{4}\right)$ at a very acidic $\mathrm{pH}(\mathrm{pH}<3)($ Eq.7) which would contribute to the improvement of the degradation of amoxicillin.

$2 \mathrm{ClO}_{4}^{-}+16 \mathrm{H}^{+}+14 \mathrm{e}^{-} \rightarrow \mathrm{Cl}_{2(\mathrm{~g})}+8 \mathrm{H}_{2} \mathrm{O}$

(7)

However, the degradation of amoxicillin on the $\mathrm{IrO}_{2}$ electrode prepared at $400^{\circ} \mathrm{C}$ is very difficult for all of the pHs explored with COD abatement rates are less than $4 \%$.

\subsubsection{Effect of $\mathrm{SO}_{4}{ }^{2-}, \mathrm{PO}_{4}{ }^{3-}, \mathrm{NO}_{3}{ }^{-}, \mathrm{Cl}^{-}$}

The contribution of inorganic ions to the degradation of amoxicillin $(1 \mathrm{~g} / \mathrm{L})$ was investigated in a neutral medium $\left(0.1 \mathrm{M} \mathrm{KClO}_{4}\right)$ containing different inorganic ions $\mathrm{SO}_{4}{ }^{2-}, \mathrm{PO}_{4}{ }^{3-}, \mathrm{NO}_{3}{ }^{-}, \mathrm{Cl}^{-}$. These ions are commonly found in real wastewater, especially in health centers. The experiments were conducted at a temperature of $25^{\circ} \mathrm{C}$ under galvanostatic conditions under a current density of $20 \mathrm{~mA} / \mathrm{cm}^{2}$ for an inorganic ion concentration of $400 \mathrm{mM}$. Normalized COD was followed. The results obtained are shown in Figure 8. This figure shows that the rate of degradation of amoxicillin is prolonged in the presence of $\mathrm{SO}_{4}{ }^{2-}$, $\mathrm{PO}_{4}{ }^{3-}, \mathrm{NO}_{3}{ }^{-}$ions. However, $\mathrm{Cl}^{-}$ions' addition has a positive effect on the degradation of amoxicillin on the $\mathrm{IrO}_{2}$ electrode. The $\mathrm{COD}$ abatement rate calculated after 10 hours of electrolysis and presented in Figure 9 gives $2.47 \% ; 2.68 \% ; 7.7 \% ; 16.41 \%$ and $71.65 \%$ respectively, in the absence of inorganic ions and in the presence of $\mathrm{SO}_{4}{ }^{2-}, \mathrm{PO}_{4}{ }^{3-}, \mathrm{NO}_{3}{ }^{-}, \mathrm{Cl}^{-} . \mathrm{SO}_{4}{ }^{2-}$ and $\mathrm{PO}_{4}{ }^{3-}$ ions have hardly any effect on amoxicillin. Some authors ${ }^{34}$ have shown that the presence of $\mathrm{SO}_{4}{ }^{2}$ ions did not positively impact the degradation of phenol on the $\mathrm{IrO}_{2}$ electrode. $\mathrm{NO}_{3}{ }^{-}$ions have a slightly positive impact on amoxicillin degradation, while the $\mathrm{Cl}^{-}$ions have a powerful and very pronounced effect on amoxicillin's degradation kinetics. Gnamba et al. showed that the presence of $\mathrm{Cl}^{-}$ions allowed to reach $100 \%$ of ceftriaxone $(1 \mathrm{~g} / \mathrm{L})$ on the BDD electrode in a neutral medium $(\mathrm{pH}=7)$. In the work of Lic A. Perea et al. ${ }^{47}$, in the presence of the $\mathrm{Cl}^{-}, 100 \%$ of the cephalexin concentration is degraded against only 2 and $5 \%$ in the presence of the $\mathrm{SO}_{4}{ }^{2-}, \mathrm{PO}_{4}{ }^{3}$, respectively. Likewise, Sindy D. Jojoa-Sierra et al. ${ }^{33}$ showed that in the presence of $\mathrm{Cl}^{-}, 70 \%$ of the antibiotic norfloxacin was eliminated on the $\mathrm{IrO}_{2}$ electrode after $20 \mathrm{~min}$ of electrolysis. On the other hand, 9 and $3 \%$ of norfloxacin was degraded in the presence of $\mathrm{SO}_{4}{ }^{2-}$ and $\mathrm{NO}_{3}{ }^{-}$respectively. According to Sindy D. Jojoa-Sierra et al., in the presence of $\mathrm{Cl}^{-}$, oxidative species are generated. They effectively contribute to norfloxacin's degradation, which is not the case for the $\mathrm{SO}_{4}{ }^{2-}$ and $\mathrm{NO}_{3}{ }^{-47}$. Contrariwise, Ana L. Giraldo et al. ${ }^{34}$ showed that the $\mathrm{NO}_{3}{ }^{-}$provided the best elimination rate $(80 \%)$ of oxacillin after 1 hour of electrolysis than $\mathrm{SO}_{4}{ }^{2-}$ (less than $25 \%$ ).

Chloride, through the formation of active chlorine would practically lead to mineralization of the initial compound. Indeed, the oxidation of chloride ions on the surface of $\mathrm{IrO}_{2}$, on the one hand, leads to the formation of active chlorine which is then hydrolyzed to give $\mathrm{HOCl}$ or $\mathrm{OCl}^{-}$(Eqs (7)-(9)) ${ }^{26}$ :

$$
\begin{aligned}
& 2 \mathrm{Cl}^{-} \rightarrow \mathrm{Cl}_{2}+2 \mathrm{e}^{-} \\
& \mathrm{Cl}_{2}+\mathrm{H}_{2} \mathrm{O} \rightarrow \mathrm{HOCl}+\mathrm{H}^{+}+\mathrm{Cl}^{-} \\
& \mathrm{HOCl} \longrightarrow \mathrm{OCl}^{-}+\mathrm{H}^{+}
\end{aligned}
$$

These oxidative species will degrade amoxicillin (Eq.(10))

$$
\mathrm{AMX}+\mathrm{HOCl}, \mathrm{OCl}^{-}, \mathrm{Cl}_{2} \rightarrow \mathrm{AMX} \text { by-products }
$$

On the other hand, the oxidation of the chloride with a hydroxyl radical bound on the $\operatorname{IrO}_{2}\left(\mathrm{IrO}_{2}\left({ }^{\circ} \mathrm{OH}\right)\right)$ indirectly produces free chlorine ${ }^{48,49}$, and the linked hydroxyl radical can lead to the possible formation of bound $\mathrm{HOCl}$ on the metal surface which can oxidize an organic substance ${ }^{50}$ (Eqs. (11)-(13)) :

$$
\begin{aligned}
& \mathrm{IrO}_{2}\left({ }^{\circ} \mathrm{OH}\right)+\mathrm{Cl}^{-} \rightarrow \mathrm{IrO}_{2}+1 / 2 \mathrm{Cl}_{2}+\mathrm{OH}^{-} \\
& \mathrm{IrO}_{2}\left({ }^{\circ} \mathrm{OH}\right)+\mathrm{Cl}^{-} \rightarrow \mathrm{IrO}_{2}(\mathrm{HOCl})+\mathrm{e}^{-} \\
& \mathrm{IrO}_{2}(\mathrm{HOCl})+\mathrm{AMX} \rightarrow \mathrm{CO}_{2}+\mathrm{H}_{2} \mathrm{O}+\mathrm{Cl}^{-}
\end{aligned}
$$

In the case $\mathrm{NO}_{3}{ }^{-}$ions, it can be reduced at the cathode to nitrite ions and ammonia $\left(\mathrm{NH}_{3}\right)$ with the formation of hydroxyl ions leading to an increase of $\mathrm{pH}$ to the reaction medium ${ }^{47}$. (Eqs (14) $-(15)$ ). $\mathrm{NH}_{3}$ could compete with amoxicillin's oxidation reaction on the electrode by electronic exchange (Eq.16) ${ }^{33}$. This could explain the slight increase in the rate of elimination of amoxicillin in the presence of $\mathrm{NO}_{3}{ }^{-}$

$$
\begin{aligned}
& \mathrm{NO}_{3}^{-}+\mathrm{H}_{2} \mathrm{O}+2 \mathrm{e}^{-} \rightarrow \mathrm{NO}_{2}^{-}+2 \mathrm{OH}^{-} \\
& \mathrm{NO}_{2}^{-}+5 \mathrm{H}_{2} \mathrm{O}+6 \mathrm{e}^{-} \rightarrow \mathrm{NH}_{3}+8 \mathrm{OH}^{-} \\
& \mathrm{NH}_{3} \rightarrow 1 / 2 \mathrm{~N}_{2}+3 \mathrm{H}^{+}+3 \mathrm{e}^{-}
\end{aligned}
$$


$\mathrm{SO}_{4}{ }^{2-}$ and $\mathrm{PO}_{4}{ }^{3-}$ ions can generate $\mathrm{S}_{2} \mathrm{O}_{8}{ }^{2-}$ and $\mathrm{P}_{2} \mathrm{O}_{8}{ }^{4-}$ (Eqs (17)-(18) $)^{51,52}$, respectively, which are powerful oxidizing agents that can oxidize organic compounds and thus increase their degradation rate. However, the generation of these oxidants in the reaction medium depends on the electrode material used at the anode. Indeed, their formation is much favored when nonactive anodes such as BDD ${ }^{51,52}$ are used. The negligible contribution of $\mathrm{SO}_{4}{ }^{2-}$ and $\mathrm{PO}_{4}{ }^{3-}$ ions on the degradation of amoxicillin on the $\mathrm{IrO}_{2}$ electrode could be explained oxidizing agents $\mathrm{S}_{2} \mathrm{O}_{8}{ }^{2-} \mathrm{P}_{2} \mathrm{O}_{8}{ }^{4-}$ are not formed during electrolysis of amoxicillin on this electrode.

$$
\begin{aligned}
& 2 \mathrm{SO}_{4}{ }^{2-} \rightarrow \mathrm{S}_{2} \mathrm{O}_{8}{ }^{2-}+2 \mathrm{e}^{-} \\
& 2 \mathrm{PO}_{4}{ }^{3-} \rightarrow \mathrm{P}_{2} \mathrm{O}_{8}{ }^{4-}+2 \mathrm{e}^{-}
\end{aligned}
$$

According to the finding below and under our working conditions, the classification of inorganic ions in increasing order of positive impact on the degradation of amoxicillin on the $\mathrm{IrO}_{2}$ electrode is follows as: $\mathrm{SO}_{4}{ }^{2-}<\mathrm{PO}_{4}{ }^{3-}<\mathrm{NO}_{3}{ }^{-}<\mathrm{Cl}^{-}$.

During electrolysis, the average current efficiency for COD was determined using the following relation $(\operatorname{Eq}(19))^{52}$

$$
\mathrm{ACE}=\frac{\mathrm{FV}\left(\mathrm{DCO}_{0}-\mathrm{DCO}_{\mathrm{t}}\right)}{8 \mathrm{I} \Delta \mathrm{t}}
$$

Where $\mathrm{COD}_{0}$ and $\mathrm{COD}_{\mathrm{t}}$ are the chemical oxygen demand (in $\mathrm{g}_{\text {of }} \mathrm{O}_{2} \mathrm{dm}^{-3}$ ) at times 0 and $\mathrm{t}$ (in seconds), respectively, $\mathrm{I}$ is the current intensity (A), $\mathrm{F}$ is the Faraday constant (96 $487 \mathrm{C} \mathrm{mol-1),} \mathrm{V} \mathrm{is} \mathrm{the} \mathrm{volume}$ of the electrolyte $\left(\mathrm{dm}^{3}\right)$, and 8 is a dimensional factor for unit consistency $\left[\left(32 \mathrm{~g}\right.\right.$ of $\mathrm{O}_{2}, \mathrm{~mol}^{-1}$ of $\left.\mathrm{O}_{2}\right) /(4 \mathrm{~mol}$ of $\mathrm{e}^{-}, \mathrm{mol}^{-1}$ of $\left.\left.\mathrm{O}_{2}\right)\right]$.

After 10 hours of electrolysis of amoxicillin in $\mathrm{KClO}_{4}$ $0.1 \mathrm{M}$ as supporting electrolyte, the average current efficiency obtained is $0.94 \%, 0.97 \%, 2.85 \%, 5.29 \%$, and $45.12 \%$, respectively, in the absence and presence of sulfate ions, phosphate ions, nitrate ions, and chloride ions. These results show that part of the current applied was used in the degradation of amoxicillin. The other part of the current could intervene in the production of reactive species that could participate in the oxidation process and/or produce undesirable side reactions like oxygen evolution reaction. ACE strongly depends on the ions present in the solution. These results show that chloride ions seem to better for the degradation of amoxicillin because it leads to the highest degradation rate of amoxicillin and reduces current losses considerably compared to other inorganic ions.

To assess the energy cost linked to amoxicillin's degradation, total energy consumption (TEC) to degrade one $\mathrm{kg}$ of COD was determined in the absence and presence of inorganic ion. The results are recorded in Table 2. The TEC was calculated using the following formula ${ }^{53}$ :

$\mathrm{TEC}=\frac{\mathrm{t} \times \mathrm{U} \times \mathrm{I}}{\mathrm{V} \times \Delta(\mathrm{COD})} \times 1000$

where $\mathrm{t}$ is the electrolysis time (h), $\mathrm{U}$ the average electrolysis cell voltage (V), I the applied electrolysis current (A), V the wastewater volume (L), and $\Delta(\mathrm{COD})$ the difference in COD $\left(\mathrm{mg} \mathrm{L}^{-1}\right)$.

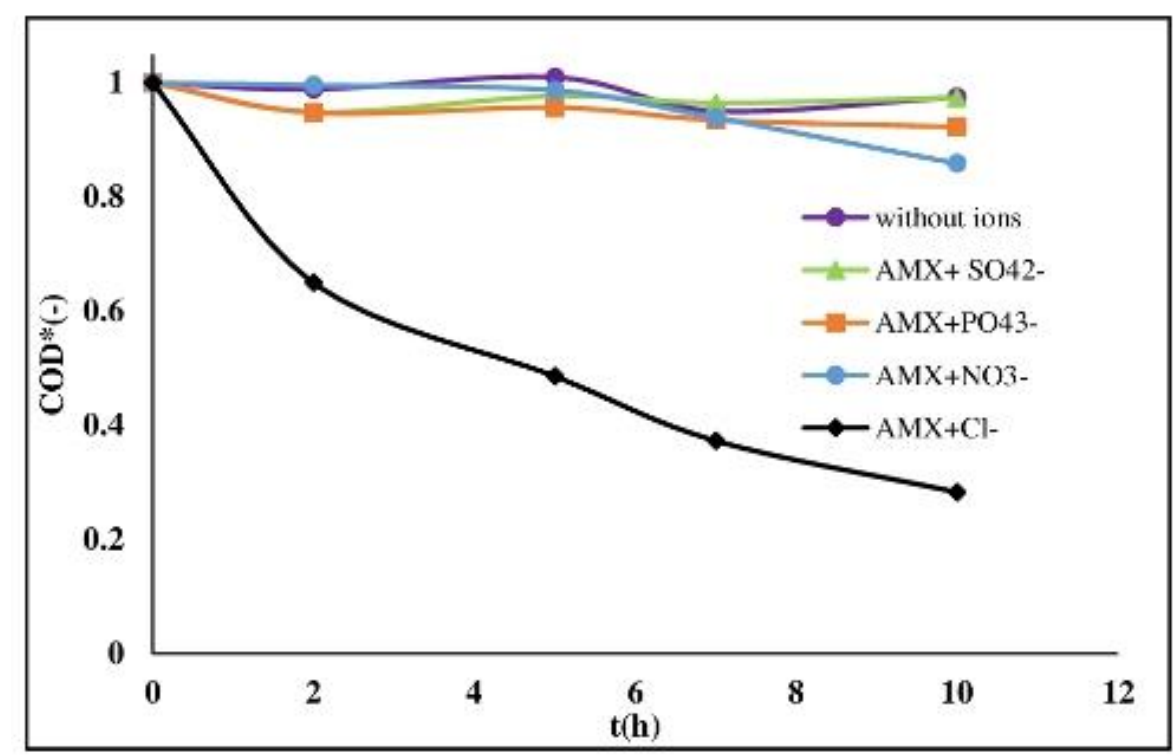

Figure 8. Effect of $\mathrm{SO}_{4}{ }^{2-}, \mathrm{PO}_{4}{ }^{3-}, \mathrm{NO}_{3}{ }^{-}, \mathrm{Cl}^{-}$ions on the electrooxidation of $1 \mathrm{~g} / \mathrm{L}$ of amoxicillin on the $\mathrm{IrO}_{2}$ electrode at current density of $20 \mathrm{~mA} / \mathrm{cm}^{2}$ 


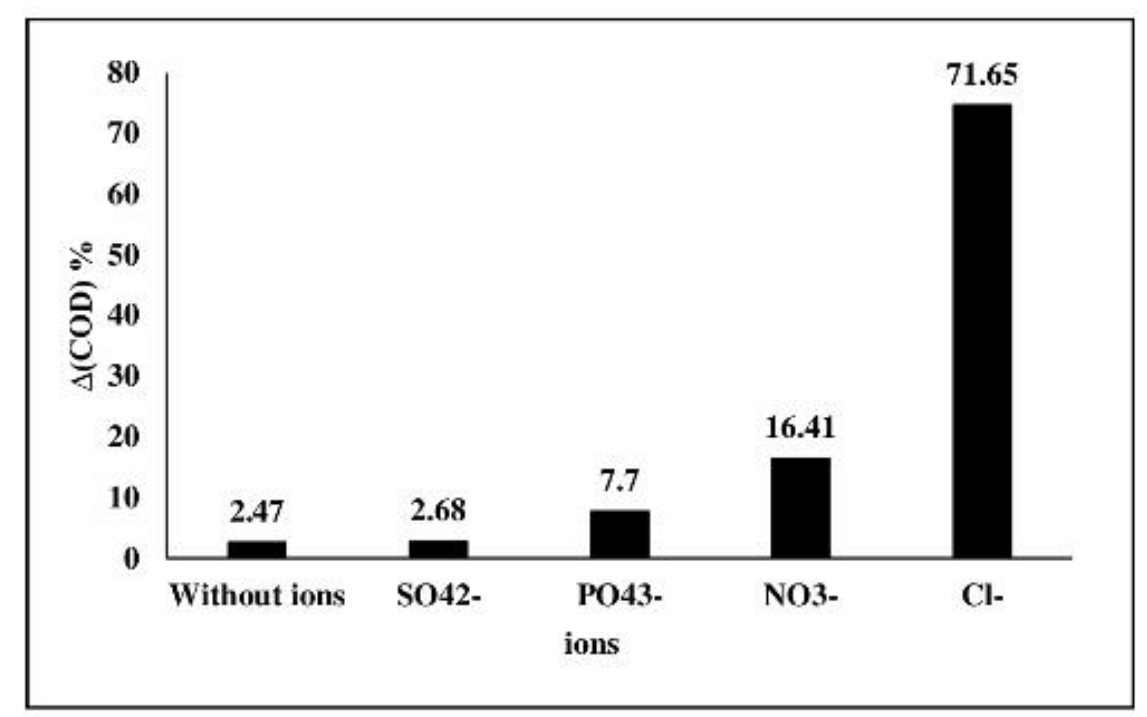

Figure 9. $\mathrm{COD}$ abatement rate according to ions $\mathrm{SO}_{4}{ }^{2-}, \mathrm{PO}_{4}{ }^{3-}, \mathrm{NO}_{3}{ }^{-}, \mathrm{Cl}^{-}$

According to Table 2, TEC values are 2928.25, 1373.41, 730.42, 287.43, and 33.19 Kwh.kg ${ }^{-1}$ COD, respectively, in the absence of inorganic ion and the presence of $\mathrm{SO}_{4}{ }^{2-}, \mathrm{PO}_{4}{ }^{3-}, \mathrm{NO}_{3}{ }^{-}, \mathrm{Cl}^{-}$. The degradation of amoxicillin in inorganic ions can significantly reduce energy consumption from $53 \%$ to $98 \%$. $\mathrm{IrO}_{2}$ electrodes can be used to treat real wastewater containing inorganic ions, especially chloride.

Table 2. Total energy consumption.

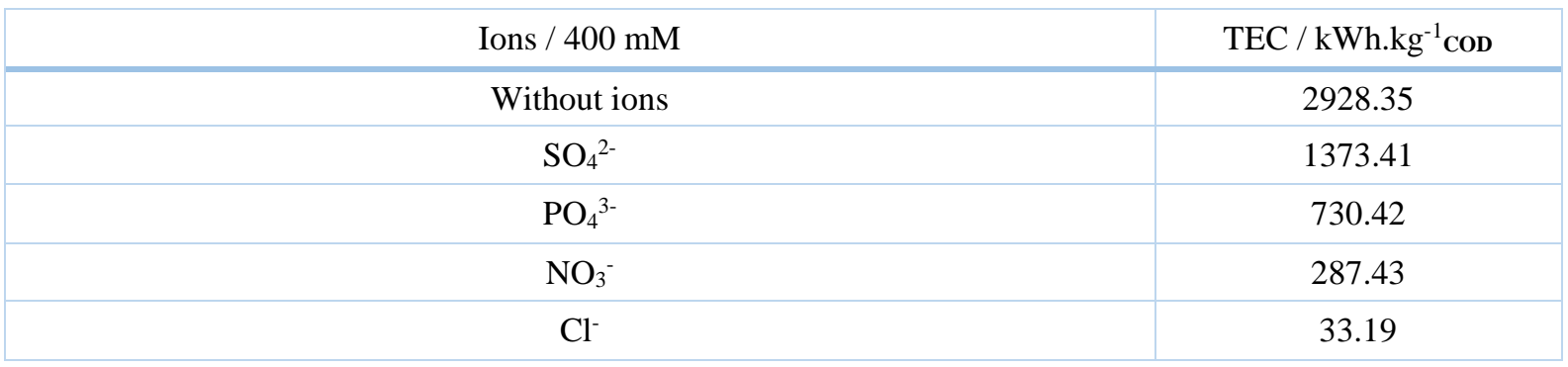

\section{Conclusion}

This work indicates that the $\mathrm{IrO}_{2}$ electrode prepared at $400^{\circ} \mathrm{C}$ has a rough surface with pores' presence. The oxidation of amoxicillin causes a deposit on its surface, causing a decrease in its electrocatalytic activity. In addition, the oxidation of amoxicillin can occur directly by the electronic exchange on the surface of $\mathrm{IrO}_{2}$ or by $\mathrm{IrO}_{3}$. The current density has a significant effect on the efficiency of this electrode. Amoxicillin degradation kinetic constant increases with current density. The supporting electrolyte and $\mathrm{pH}$ also affect the removal of amoxicillin at the $\mathrm{IrO}_{2}$ electrode. The degradation of this compound is favored in a very acidic medium. However, this degradation remains very low and is less than $11 \%$ of the elimination rate, indicating that amoxicillin's degradation leads to converting the parent compound into reaction intermediates.

The effect of some ions commonly found in hospital wastewater was investigated on simulated wastewaters containing $1 \mathrm{~g} / \mathrm{L}$ of amoxicillin. These studies show that these ions' effects are diverse, with COD reduction rates ranging from $2.47 \% ; 2.68 \%$; $7.7 \% ; 16.41 \%$, and $74.65 \%$, respectively in the absence and presence of $\mathrm{SO}_{4}{ }^{2-}, \mathrm{PO}_{4}{ }^{3-}, \mathrm{NO}_{3}{ }^{-}, \mathrm{Cl}^{-}$. Sulfate ions have virtually no effect on enhancing the degradation of amoxicillin. Phosphate ions provide a slight improvement in the breakdown of amoxicillin. As for nitrate ions, their effect is 2.31 times that of phosphate ions. In solution, nitrates are reduced at the cathode to nitrites and ammonia. The latter would compete with the degradation of amoxicillin via electron transfer. Chloride ions very significantly improve the performance of the electrooxidation of amoxicillin on $\mathrm{IrO}_{2}$. The oxidative species resulting from the chloride ions participate effectively in the degradation of the organic compound. The presence of ions, especially chloride ions, makes it possible to go from 2928.35 (absence of inorganic ions) to 33.19 $\mathrm{kWh}$ per $\mathrm{Kg}$ of COD. This represents an energy gain of over $98 \%$.

This electrode could be used to treat real wastewater containing inorganic ions, especially chloride in large quantities.

\section{Acknowledgments}

We greatly thank the Swiss National Funds for its financial support that allowed this work to be carried 
out. Our Team has received part of the grant IZ01Z0_146919 for that work.

\section{References}

1- S. P. Sadia, M. Berté, E. M. H. Loba, F. T. A. Appia, C. Q.-M. Gnamba, S. Ibrahima, L. Ouattara, Assessment of the Physicochemical and Microbiological Parameters of a Teaching Hospital's Wastewaters in Abidjan in Côte d'Ivoire, J. of Wat. Res. and Protect., 2016, 8, 1251-1265.

2- A. Shabnam, Y. Yavuz, S. Zühre, Electrooxidation of tetracycline antibiotic demeclocycline at unmodified boron-doped diamond electrode and its enhancement determination in surfactant-containing media, Talanta, 2021, 223, 121695.

3- J. Wang, R. Zhuan, L. Chu, The occurrence, distribution and degradation of antibiotics by ionizing radiation: an overview, Sci. Total Environ., 2019, 646, 1385-1397.

4- N. Koch, N. F. Islam, S. Sonowal, R. Prasad, H. Sarma, Environmental antibiotics and resistance genes as emerging contaminants: methods of detection and bioremediation, Curr. Res. Microbial. Sci., 2021. doi:10.1016/j.crmicr.2021.100027.

5- J. L. Wilkinson, P. S. Hooda, J. Barker, S. Barton, J. Swinden, Ecotoxic pharmaceuticals, personal care products, and other emerging contaminants: A review of environmental, receptor-mediated, developmental, and epigenetic toxicity with discussion of proposed toxicity to humans, Crit. Rev. Environ. Sci. Technol., 2016, 46, $336-381$. doi: $10.1080 / 10643389.2015 .1096876$.

6- J. Du, H. Zhao, Y. Wang, H. Xie, M. Zhu, J. Chen, Presence and environmental risk assessment of selected antibiotics in coastal water adjacent to mariculture areas in the Bohai Sea, Ecotoxicol. and Environ. Saf., 2019, 177, 117-123.

7- A. Ezzariai, M. Hafidi, A. Khadra, Q. Aemig, L. El Fels, M. Barret, G. Merlina, D. Patureau, E. Pinelli, Human and veterinary antibiotics during composting of sludge or manure: global perspectives on persistence, degradation, and resistance genes, J. Hazard Mater., 2018, 359, 465-481. doi: 10.1016/j.jhazmat.2018.07.092.

8- L. Patrolecco, J. Rauseo, N. Ademollo, P. Grenni, M. Cardoni, C. Levantesi, M. L. Luprano, A. B. Caraccio- lo, Persistence of the antibiotic sulfamethoxazole in river water alone or in the co-presence of ciprofloxacin, Sci. Tot. Environ., 2018, 640-64, 1438-1446.

9- H. Q. Anh, T. P. Q. Le, N. D. Le, X. X. Lu, T. T. Duong, J. Garnier, E. Rochelle-Newall, S. Zhang, O. Neung- Hwan, C. Oeurng, C. Ekkawatpanit, T. D. Nguyen, Q. T. Nguyen, T. D. Nguyen, T. N. Nguyen, T. L. Tran, T. Kunisue, R. Tanoue, S. Takahashi, T.B. Minh, H.T. Le, T.N.M. Pham,
T.A.H. Nguyen, Antibiotics in surface water of East and Southeast Asian countries: A focused review on contamination status, pollution sources, potential risks, and future perspectives, Sci. of the Tot. Environ., 2020. doi: $10.1016 /$ j.scitotenv.2020.142865.

10-M. Gavrilescu, K. Demnerová, J. Aamand, S. Agathos, F. Fava, Emerging pollutants in the environment: present and future challenges in biomonitoring, ecological risks and bioremediation, N. Biotech., 2015, 32 (1), 147-156.

11-S. Bergeron, B. Raj, N. Rajkumar, A. Corbin, G. LaFleur, Presence of antibiotic resistance genes in raw source water of a drinking water treatment plant in a rural community of USA, Int. Biodeterior. Biodegrad., 2017, 1-7.

12-P. Kovalakova, L. Cizmas, T. J. McDonald, B. Marsalek, M. Feng, V. K. Sharma, Occurrence and toxicity of antibiotics in the aquatic environment: A review, Chemosphere, 2020, 251,126351

13-M. Klavarioti, D. Mantzavinos, D. Kassinos, Removal of residual pharmaceuticals from aqueous systems by advanced oxidation processes, Environ. Int., 2009, 35, 402-417.

14-B. Yang, G. Chen, G. Chen, Submerged membrane bioreactor in treatment of simulated restaurant wastewater, Sep. Purif. Technol., 2012, 88, 184-190.

15-A. Radka, T. Kümpel, K. Kümmerer, Assessment of degradation of 18 antibiotics in the Closed Bottle Test, Chemosphere, 2004, 57(6), 505-512.

16-M. Klavarioti, D. Mantzavinos, D. Kassinos, Removal of residual pharmaceuticals from aqueous systems by advanced oxidation processes, Environ. Int, 2009, 35, 402-417.

17-M. F. García-Montoya, S. Gutiérrez-Granados, A. Alatorre-Ordaz, R. Galindo, R. Ornelas, J. M. Peralta- Hernández, Application of electrochemical/BDD process for the treatment wastewater effluents containing pharmaceutical compounds, J. Ind. Eng. Chem, 2015, 31, 238-243.

18-L. P. Bao, C. O. Chong, S. M. S. Mohamed, S. Pau-Loke, C. Jo-Shu, C. L. Tau, S. L. Su, C. J. Joon, Conventional and Emerging Technologies for Removal of Antibiotics from Wastewater, J. Hazar. Mater., 2020. doi: 10.1016/j.jhazmat.2020.122961.

19-V. Punturat, K.-L. Huang, Degradation pathways and organic matter transformation of acesulfame potassium electrooxidation in real water matrices, J. Taiwan Inst. Chem. Eng., 2017, 80, 222-230.

20-J. Mora-Gomez, E. Ortega, S. Mestre, V. PérezHerranz, M. García-Gabaldón, Electrochemical degradation of norfloxacin using BDD and new $\mathrm{Sb}$-doped $\mathrm{SnO}_{2}$ ceramic anodes in an electrochemical reactor in the presence and absence of a cation-exchange membrane, Sep. Pur. Technol., 2018. 
doi: 10.1016/j.seppur.2018.05.017.

21- J. L. D. S. Duarte, A. M. S. Solano, M. L. P. M. Arguelho, J. Tonholo, C. A. Martínez-Huitle, C. L. de Paiva, S. Zant, Evaluation of treatment of effluents contaminated with rifampicin by Fenton, electrochemical and associated processes, J. Water Process Eng., 2018, 22, 250-257.

22-E. Brillas, C. A. Martínez-Huitle, Decontamination of wastewaters containing synthetic organic dyes by electrochemical methods. An updated review, Appl. Catal. B Environ., 2015, 166-167, 603-643.

23-S. Vasilie, F. Manea, A. Baciu, A. Pop, Dual use of boron-doped diamond electrode in antibioticscontaining water treatment and process control, Process Saf. Environ., 2018, 117, 446-453.

24-Z. Frontistis, M. Antonopoulou, D. Venieri, I. Konstantinou, D. Mantzavinos, Boron-doped diamond oxidation of amoxicillin pharmaceutical formulation: Statistical evaluation of operating parameters, reaction pathways and antibacterial activity, J. Environ. Manage., 2017, 195 (2), 100-109.

25-Q. Dai, J. Zhou, M. Weng, X. Luo, D. Feng, J. Chen, Electrochemical oxidation metronidazole with $\mathrm{Co}$ modified $\mathrm{PbO}_{2}$ electrode: Degradation and mechanism, Sep. Purif. Technol., 2016, 166, 109-116.

26- D. Rosestolato, J. Fregoni, S. Ferro, A. De Battisti, Influence of the nature of the electrode material and process variables on the kinetics of the chlorine evolution reaction. The case of $\mathrm{IrO}_{2}-$ based electrocatalysts, Electrochim. Acta, 2014, 139, 180-189. doi: $10.1016 /$ j.electacta.2014.07.037.

27-D. Sun, X. Hong, K. Wu, K. S. Hui, Y. Du, K. N. Hui, Simultaneous removal of ammonia and phosphate by electrooxidation and electrocoagulation using $\mathrm{RuO}_{2}-\mathrm{IrO}_{2} / \mathrm{Ti}$ and microscale zero-valent iron composite electrode, water Res., 2020, 169, 115239.

28-F. Zaviska, P. Drogui, J.-F. Blais, G. Mercier, P. Lafrance, Experimental design methodology applied to electrochemical oxidation of the herbicide atrazine using $\mathrm{Ti} / \mathrm{IrO}_{2}$ and $\mathrm{Ti} / \mathrm{SnO}_{2}$ circular anode electrodes, J. Hazard. Mater., 2011, 185, 1499-1507.

29-M. Li, C. Feng, W. Hub, Z. Zhanga, N. Sugiura, Electrochemical degradation of phenol using electrodes of $\mathrm{Ti} / \mathrm{RuO}_{2}-\mathrm{Pt}$ and $\mathrm{Ti} / \mathrm{IrO}_{2}-\mathrm{Pt}$, J. Hazard. Mater., 2009, 162, 455-462.

30-K. Ollo, P. L. A. Guillaume, A. F. T. Auguste, G. C. Quand-Meme, K. K. Honoré, O. Lassiné, Influence of various metallic oxides on the kinetic of the oxygen evolution reaction on platinum electrodes, J. Electrochem. Sci. Eng., 2015, 5(2), 79-91. doi: 10.5599/jese.157.

31-L. Bao, W. Chengyan, C. Yongqiang, M. Baozhong, Electrochemical behavior and corrosion mechanism of $\mathrm{Ti} / \mathrm{IrO}_{2}-\mathrm{RuO}_{2}$ anodes in sulphuric acid solution, J. Electroanal. Chem., 2019, 837, 175-183.

32-H. Cao, M. Chen, L. Wu, G. Hou, Y. Yiping Tang, G. Zheng, Electrochemical properties of $\mathrm{IrO}_{2}$ active anode with TNTs interlayer for oxygen evolution, Appl. Surf. Sci., 2018, 428, 861-869.

33-S. D. Jojoa-Sierra, J. Silva-Agredo, E. HerreraCalderon, R. A. Torres-Palma, Elimination of the antibiotic norfloxacin in municipal wastewater, urine and seawater by electrochemical oxidation on $\mathrm{IrO}_{2}$ anodes, Sci. Total Environ., 2017, 575, 1228-1238.

34-A. L. Giraldo, E. D. Erazo-Erazo, O. A. FlorezAcosta, E. A. Serna-Galvis, R. A. Torres Palma, Degradation of the antibiotic oxacillin in water by anodic oxidation with $\mathrm{Ti} / \mathrm{IrO}_{2}$ anodes: Evaluation of degradation routes, organic byproducts and effects of water matrix components, Chem. Eng. J., 2015, 279, 103-114.

35-E. Chatzisymeon, A. Dimou, D. Mantzavinos, A. Katsaounis, Electrochemical oxidation of model compounds and olive mill wastewater over DSA electrodes: 1 . The case of $\mathrm{Ti} / \mathrm{IrO}_{2}$ anode, J. Hazard. Mater., 2009, 167, 268-274.

36-E. Chatzisymeon, S. Fierro, I. Karafyllis, D. Mantzavinos, N. Kalogerakis, A. Katsaounis, Anodic oxidation of phenol on $\mathrm{Ti} / \mathrm{IrO}_{2}$ electrode: Experimental studies, Catal. Today, 2010, 151, 185-189.

37-N. Jiang, Y. Wang, Q. Zhao, Z. Ye, Application of $\mathrm{Ti} / \mathrm{IrO}_{2}$ electrode in the electrochemical oxidation of the TNT red water, Environ. Pollut., 2020, doi: 10.1016/j.envpol.2019.113801.

38-F. Sopaj, M. A. Rodrigo, N. Oturan, F. I. Podvorica, J. Pinson, M. A. Oturan, Influence of the anode materials on the electrochemical oxidation efficiency. Application to oxidative degradation of the pharmaceutical amoxicillin, Chem. Eng. J., 2015, 262, 286-294.

39-A. M. S. Sales, C. K. C. Araujo, J. V. Melo, J. M. Peralta-Hernandez, D. R. Silva, C. A. MartinezHuitle, Decontamination of real textile industrial effluent by strong oxidant species electrogenerated on diamond electrode: viability and disadvantages of this electrochemical technology, Appl. Catal. B, 2013, 130-131, 112-120.

40-M. G. Tavares, L.V. A. Silva, A. M. S. Sales, J. Tonholo, C. A. Martinez-Huitle, C. L. P. S. Zanta, Electrochemical oxidation of Methyl Red using $\mathrm{Ti} / \mathrm{Ru}_{0,3} \mathrm{Ti}_{0,7} \mathrm{O}_{2}$ anodes, Chem. Eng. J., 2012, 204-206, 141-150.

41-O. I. Anglada, A. Urtiaga, I. Ortiz, Contributions of electrochemical oxidation to wastewater treatment: fundamentals and review of applications, J. Chem. Technol. Biotechnol., 2009, 84, 1747-1755.

42-S. Periyasamy, M. Muthuchamy, Electrochemical oxidation of paracetamol in water by graphite anode: Effect of $\mathrm{pH}$, electrolyte concentration 
and current density. J. Environ. Chem. Eng., 2018.

doi: $10.1016 /$ j.jece.2018.08.036.

43-S. A. Neto, A. R. de Andrade, Electrooxidation of glyphosate herbicide at different DSAR compositions: $\mathrm{pH}$, concentration and supporting electrolyte effect, Electrochim. Acta, 2009, 54, 2039-2045.

44-C. Q. M Gnamba, F. T. A. Appia, E. M. H. Loba, M. Berthe, S. P. Sadia, S. Ibrahima, L. Ouattara, Electrooxidation of Ceftriaxone in Its Commercial Formulation on Boron Doped Diamond Anode, J. Adv. Electro- chem., 2016, 2(2), 85-88.

45-R. E. Palma-Goyes, J. Silva-Agredo, J. VazquezArenas, I. Romero-Ibarra, R. A. Torres-Palma, The effect of different operational parameters on the electrooxidation of Indigo Carmine on $\mathrm{Ti} / \mathrm{IrO}_{2}-\mathrm{SnO}_{2}-\mathrm{Sb}_{2} \mathrm{O}_{3}$, J. Environ. Chem. Eng., 2018. doi: $10.1016 /$ j.jece.2018.04.035.

46-N. Wachter, J. M. Aquino, M. Denadai, J. C. Barreiro, A. Jose Silva, Q. B. Cass, N. Bocchi, R. C. Rocha- Filho, Electrochemical degradation of the antibiotic ciprofloxacin in a flow reactor using distinct BDD anodes: Reaction kinetics, identification and toxicity of the degradation products, Chemosphere, 2019, 234, 461- 470.

47-L. A. Perea, R. E. Palma-Goyes, J. VazquezArenas, I. Romero-Ibarra, C. Ostos, R. A. TorresPalma, Efficient cephalexin degradation using active chlorine produced on ruthenium and iridium oxide anodes: Role of bath composition, analysis of degradation pathways and degradation extent, Sci. Total Environ., 2019, 648, 377- 387.

48-S. Hong, T-k. Lee, M. R. Hoffmann, K. Cho, Enhanced chlorine evolution from dimensionally stable anode by heterojunction with $\mathrm{Ti}$ and $\mathrm{Bi}$ based mixed metal oxide layers prepared from nanoparticle slurry, J. Catal., 2020. doi: 10.1016/j.jcat.2020.04.009.

49-K. Cho, M. R. Hoffmann, BixTi1-xOz functionalized heterojunction anode with an enhanced reactive chlorine generation efficiency in diluted aqueous solutions, Chem. Mater., 2015, 27, 2224-2233.

50-F. Bonfatti, S. Ferro, F. Lavezzo, M. Malacarne, G. Lodi, A. De Battisti, 2000. Electrochemical incineration of glucose as a model organic substrate. II role of active chlorine mediation, J. Electrochem. Soc., 2000, 147, 592-596.

51-P. Cañizares, F. Larrondo, J. Lobato, M. A. Rodrigo, C. Sáez, Electrochemical synthesis of peroxodiphosphate using boron-doped anodes, J. Electrochem. Soc., 2005, pD191-D196.

52-P. Cañizares, C. Sáez, J. Lobato, M. A. Rodrigo, Electrochemical Oxidation of Polyhydroxybenzenes on Boron-Doped Diamond Anodes, Ind. Eng. Chem. Res., 2004, 43, 6629-6637.

53-K. P. De Amorim, L. L. Romualdo, L. S. Andrade, Electrochemical degradation of sulfamethoxazole and trimethoprim at borondoped diamond electrode: Performance, kinetics and reaction pathway, Sep. Purif. Technol., 2013, 120, 319-327. 